\title{
Challenges and Countermeasures of Ideological and Political Work in Colleges and Universities in the New Media Era
}

\author{
CHEN Dong ${ }^{1, a}$ \\ ${ }^{1}$ Ideological and Political Theory Course Teaching and Research Department, Minjiang university, \\ Fuzhou, Fujian 350121, China \\ a23505774@qq.com
}

\begin{abstract}
With the development of information technology, the coming of new media era brings new changes to the ideological and political education in colleges and universities. Some problems exist in the new media era, there innovation and development countermeasures of ideological and political education are that using new media to update the concept of college ideological and political education; innovative ways of ideological and political education in colleges and universities; strengthen the construction of teaching team and strengthen the new media literacy education of college students.
\end{abstract}

Keywords: The new media era; universities; ideological education; innovation research

\section{Introduction}

In recent years, with the emergence of new media, new media has been widely used in life. New media generally refers to the digital technology, Internet technology and mobile communication technology as the technical basis, and to provide users with the information of the new media. Such as network, micro-blog and mobile phone text messages, etc. Compared to newspapers, radio, television and other traditional media, the new media is more interactive, shared, to meet the fast pace of contemporary life characteristics, in people's lives to be quickly applied. College students as a group who have accepted and used new things, in the era of new media, their ideas are easily affected. Therefore, it is very important to study the ideological and political education in colleges and universities in the new media era ${ }^{[1]}$.

\section{A survey of the application of ideological and political education in colleges and universities in new media}

New media is gradually integrated into the growth of college students, QQ, micro-blog, we chat, almost every college students are able to skillfully use; these have become a part of the university life. At the same time, the new media has been widely used in classroom teaching, and it has been widely used in classroom teaching, and it has been accepted by the positive and open attitude. How to guide college students to use the new media effectively and promote the all-round development of individuals is the main problem facing the new media in the face of the new media. Now college students' independent and strong, outstanding personalized, new media interactive, personalized caters to their characteristics. Therefore, the teaching of ideological and political education in colleges and universities with these new media tools, very easy to let the students to accept, also contributed to the realization of the teaching effect. In addition, students can learn the contents of the lesson, instant interactive communication, to express their views, more conducive to enhancing the permeability of teaching ideas. Of course, the new media is not only applied to bring convenience at the same time, but also has its drawbacks. Such as new media information dissemination without shielding, the proliferation of bad information, college students are vulnerable to the impact of this negative information. In short, the application of new media in the university must pay attention to service teaching, on the other hand, to deal with its negative side, to prevent and deal with the work. 


\section{Characteristics of ideological and political education in colleges and universities in the new media era}

1 New media provides a broad platform for ideological and political education in colleges and universities.

High speed of communication and richness of information are the outstanding features of the new media era. Ideological and political education in colleges and universities through the application of new media, it is easy to break away from the traditional teaching mode, there are more options, such as sound, video and other ways to enrich the teaching methods. In the communication between teachers and students, students have a problem, with the help of new media in a timely manner to the teacher asked, more willing to open his heart to communicate with their teachers and express their true thoughts; as a teacher, not only is the receiver and publisher, you can use new media information resources are abundant and a lot of teaching information release, and the interaction between students [2].

2 New media for the ideological and political education in colleges and universities to save the cost of teaching

Traditional ideological and political education, not only need a lot of ideological and political teachers of physical education, but also need a huge financial resources to do, the cost of resource consumption is too large. And new media is simple and easy to use, fast and convenient features, through the application of electronic information and network to greatly save communication costs and reduce the consumption of office supplies; in addition, the traditional "speak" education, occupy more hours, but the effect is not ideal, and the time length is proportional to, time cost is too high, but with the application of new media, students could accept the text, sound, video and other forms of teaching, help to knowledge of understanding and master, thus greatly reducing the time cost.

\section{The challenges of the new media to the ideological and political education in colleges and universities}

1 Ignore the cultivation of college students' living communication ability

In the new media environment, the exchange interaction is open, free and virtual, and the communication between strangers is hidden and irresponsible, so it is popular with the young college students. There are many students, they usually live in quiet, unknown to the public, but in network world is dominated the other a lot of appearance, and indulge in the virtual network paralysis of their own. It is not difficult to find, this kind of college students a lot of mobile phones and computers have excessive dependence on the class play mobile phones, class staring at the computer playing games or watching movies, the phenomenon is not uncommon. However, college students need is real life, in real life to cultivate their interests and hobbies, exercise their social skills, and not to refuse the real life. Based on the contradiction between virtual and reality, the new media environment has a negative impact on the growth of college students ${ }^{[3]}$.

2 Weakening the role of ideological and political education and textbook knowledge

The traditional ideological and political education, teachers are the dominant ideological and political education; textbooks are the carrier of knowledge, with the help of textbooks to impart knowledge. Teachers, textbooks, students, the three constitute the core system of knowledge education. Nowadays, the appearance of the developed media breaks the pattern. New media forms of information dissemination, weakening the status of teachers. Moreover, in the new media information, some advocates hedonism and money worship and other bad ideas. A negative impact of the values and outlook on life of college students. All in all, the emergence of new media, partly to replace the ideological and political education and textbooks, the formation of a direct relationship between college students and the new media, is weakening the importance of ideological and political education and textbook knowledge.

3 To increase the difficulty of ideological and political education work in colleges and universities 
The emergence of new media, the mode of traditional education is a big challenge, at this stage, the pace of the reform of ideological and political education in colleges and universities can not catch up with the rapid development of new media, facing some new situations and new problems. In terms of environmental education, new media to enhance the students' subject consciousness, the university to continue the traditional classroom one-way indoctrination teaching, will make the effect is greatly reduced; in terms of the content of the textbook, or just focus on content, pay attention to knowledge system construction, don't mention the learning interests of students, resulting in their focus on the phone, and so on sleep, affect the realization of teaching effect. These questions will undoubtedly increase the difficulty of the education of ideological and political teachers.

\section{The innovation and development of ideological and political education in colleges and universities in the new media era}

1 Using the new media to update the ideological and political education concept

To deal with the new changes in the teaching work of the new media, the ideological and political education workers in colleges and universities need to renew the educational concept of the educators. First, the concept of modern education is the premise of realizing the modernization of education, the continuous application and development of new media at the same time, educators must accept new media, take the initiative to do new media users, improve their own modern education concept, for the modernization of education realize long-term hit count. Teachers can use the new media as their own teaching tools, the use of the characteristics of the new media, rational use, and innovate their own teaching methods, so that they serve the teaching. Secondly, for the school, should also to open attitude and eclectic use of new media to carry out ideological and political education work, encourage teachers and students to use new media, increase the propaganda of the application of new media technology. To study the combination of new media and teaching work, develop a new teaching model, and apply the new media to the teaching work. In the reasonable application of new media technology, but also to pay attention to science, for the drawbacks of the new media, in advance to prevent measures, the negative impact of the new media on students to a minimum ${ }^{[4]}$.

2 Using the new media to innovate the way of ideological and political education in universities

The emergence of new media provides the conditions for the innovation of the ideological and political education in colleges and universities. First of all, to change the previous text alone, said imparting knowledge of the situation, increase the theoretical course of ideological and political education of classroom interaction, through the application of new media, text, voice, video and other media common services in education; increase the class interaction between teachers and students of, with the help of micro blog, micro channel, such as instant communication tool, and college students in the class to achieve information exchange, is no longer just a classroom lecture format. Secondly, the construction of the exchange of information platform for the exchange of ideas, to create a new system of communication between teachers and students can participate. Teachers can be released in the above real-time information, technology, health, psychology and other aspects of information, for college students to study and discussion; college students can also through this platform, to solve some problems of its own, released some of their thought experience, interactive communication with you. Finally, the class can set up their own class information exchange group, by counselor leadership and some information about the class can be in here to share, a problem we dealt with, activities together to participate in the completion, forming a love of the collective.

3 Using the new media to strengthen the construction of teaching staff of ideological and political education in colleges and universities

The effect of ideological and political education of college students is good or bad, in the final analysis is the problem of people. In the new media era, it is necessary to strengthen the ideological and political education in colleges and universities; therefore, it is imperative to strengthen the construction of ideological and political education teaching staff. Ideological and political education 
workers must have excellent ideological and political quality and new media technology application ability. Ideological and political teachers of the Mao Zedong thought, the socialist theory of Chinese characteristics, the content of the master, just a part of the teaching, but also the ability to combine the application of new media technology to carry out ideological and political education. The former can be solved by the educator himself, and the latter needs the joint efforts of the school and the teacher. Schools for teachers of specialized technical training for new media, set the relevant training courses, improve the teachers' ability to apply for new media teaching and solve the problems appeared in the process of the new media applications, summed up a new model for teaching, to moment to adapt to the new environment.

4 Using the new media to strengthen the new media literacy education for college students

The university students are greatly influenced by the environment of the new media era, and become an important way to realize the society, to know themselves, how to understand and use the media correctly, and have become a subject of university education. Media literacy has its rich connotation, mainly refers to the people in the face of a variety of information media has the ability to interpret. That is to say, in our country current new media environment, how to get the correct information from the new media, the need for good media literacy, especially college students. Therefore, colleges and universities should strengthen the education of College Students' media literacy. First of all, in the university education, to teach students the knowledge of media literacy education, through a number of courses, lectures, etc., to carry out educational work, and guide students to have a correct understanding of the media. College students have a preliminary understanding of the need for real life in the use of. So, universities can carry out the corresponding practice activities, for example, micro-blog create competition, Internet knowledge contests, and other, let the students involved, to practice promote the understanding and use of new media, cultivate students distinguish between the information thinking and independent thinking ability ${ }^{[5]}$.

\section{Summary}

Under the new media era of ideological and political education is the needs of times development, is the need for the innovation and development of education mode, the only active acceptance of new media, does not exclude, new media teaching application, and actively respond to its negative effects, contribute to the innovation and development of education mode. First analysis of China's current ideological education situation, summed up the ideological and political education in colleges and universities under the new media environment the new features of the new situation, at the same time, the application of new media technology to the ideological and political education in our colleges and universities brought challenges, lists the three main problems. Finally, this paper puts forward under the new situation of innovation of ideological and political education in colleges and universities several suggestions and measures, to bring a bit enlightenment and help to the work of ideological and political education of colleges and universities in our country. New media is quickly into our lives, has become an inseparable part of our life, it will fundamentally change students' way of life and way of thinking. Therefore, it is necessary to correct guidance to college students. Strengthen the ideological and political education of college students, combined with the application of new media, to promote the socialist core value system, so that students can be fully developed. In the future, there will be a new breakthrough in the teaching, and the application of technology, which makes the teaching mode innovation and development.

\section{References}

[1] Wang Hong. Digital technology and new media [M]. Beijing: Communication University of China press 2015.

[2] Wang Xinlan under the new media environment. The development of Ideological and political education innovation of [J]. School of Party construction and ideological education, 2015 (3). 
[3] Zheng Yuanjing under the new media environment. The effectiveness of Ideological and political education of the theory of [J]. education Herald, 2014 (11).

[4] Qu Hai Xiang. Study on [J]. education of College Students' Ideological and political work under the new media environment, 2013 (3).

[5] G.R. Mettam, L.B. Adams, How to prepare an electronic version of your article, in: B.S. Jones, R.Z. Smith (Eds.), Introduction to the Electronic Age, E-Publishing Inc., New York, 1999, pp. 281-304. 